\title{
7 \\ A Voyeur on a Collective Farm
}

\section{Closely Observed Farms}

In1920, Babel' went to war, suggests Odessajournalist Elena Karakina, much like Josephus Flavius, as Leon Feuchtwanger portrayed the Jewish general who went over to the Romans, as a correspondent to history, in order to witness the most terrifying cruelty without flinching, without betraying his empathy and kinship with the victims. ${ }^{1}$ However, Josephus' ethical position remains controversial. There can be little doubt as to Babel"s sympathies when writing his 1920 Diary, nor should we mistake the moral position of the author in Red Cavalry. But the stories Babel' wrote about collectivization (which were to form part of a book, Velikaia krinitsa) ${ }^{2}$ and about industrialization - of which we have only one, "Oil" ("Нефть", 1934) - do leave us with disturbing questions about the ethics of narration, not least the apparent absence of an authorial position. By the onset of the campaign of forced collectivization, Babel' could have no delusions, for all his idealism. And yet there is scarcely any evidence in these stories that he ever betrayed his misgivings or his personal feelings about what was done in the name of the building of socialism.

Babel' had the opportunity to observe collectivization at close hand in Molodenovo, where his life was idyllic, both because of its proximity to Gor'ky and the quiet it afforded to get on with his work uninterrupted, not to mention bathing in the Moskva River in the summer. Sometimes he would take a scythe and help with the harvesting. ${ }^{3}$ The peasants affectionately called him Isai Imuilovich, and he worked for a while as secretary of the village council, as 
well as observing breeding on the stud farm. ${ }^{4}$ On 16 February 1930, Babel' informed his family abroad that he was leaving for an area of intense collectivization in the Borispol' district in the Kiev region, which was transforming Soviet agriculture and village life. He would never forgive himself, he wrote, if he missed seeing this process with his own eyes "both because it is interesting in itself and because it has a significance transcending anything we have seen." ${ }^{5}$ To his schoolfriend from Odessa, Isai Livshits, he wrote from Borispol' on 20 February 1930, that he found this area of intensive

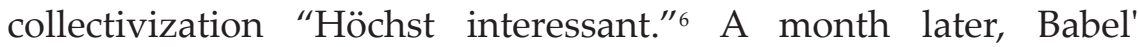
returned to Kiev sick and exhausted. His friend M. Y. Makotinski, who worked with him at the VUFKU film studios, was at this time expecting NKVD agents to arrest him and was frightened out of his wits by a furious pounding on the door of his apartment in the middle of the night. Only after some time did he open the door to discover Babel' covered in snow, shivering with cold. He had been following the collectivization process and was shaken by what he saw in village after village: You cannot imagine! It is inexpressible, what I have observed in the village! And not just in one village! It is impossible to even describe! I do not understand an-y-thing!" (“Вы себе представить не можете! Это непередаваемо-то, что я наблюдал на селе! Инев одном селе! Это и описать невозможно! Я ни-че-го не по-ни-маю!" $)^{7}$

After observing the collectivization campaign, and before he returned to Moscow in April, Babel' visited the construction site of the huge industrial complex on the Dnieper and in later years he travelled round mines, farms, and factories all over the country. Later he was to tell Ervin Sinkó, his Hungarian émigré neighbor in Moscow, of the eerie silence of villages where no dog dared bark. ${ }^{8}$ And this is how "Gapa Guzhva," the first chapter in Babel"s projected book, Velikaia Krinitsa, ends:

Безмолвие распростерлось над Великой Криницей, над плоской, могильной, обледенелой пустыней деревенской ночи. (Собрание сочинений, III, 158)

Silence spread over Velikaia Krinitsa, over the flat, sepulchral, frozen desert of the village night. (Complete Works, 651) 
Nevertheless, in his letters to his family abroad, which were filled as always with financial and family anxieties and were written with the censor in mind, Babel' effused praise for the success of collectivization in the Caucuses, which was bringing unprecedented economic benefits and limitless vistas on an impressive scale (such as the largest poultry farm in the world), despite the "hardships" suffered. ${ }^{9}$ After going down a mine in Gorlovka (in the Don Valley) he enthused about industrialization: "The spirit of hope and triumph here now is greater than at any time during the sixteen years since the Revolution." ${ }^{10}$ On another trip to the area, collecting facts for work in progress at the height of the Stakhanovite movement, he spoke of "the mighty energy and vigor seething in this region, which is the real steel, coal, and electric heart of our great country." ${ }^{11} \mathrm{He}$ also visited the Jewish agricultural colonies in the Ukraine and Crimea under the auspices of OZET, the Jewish agricultural settlement program. However, Babel' does not seem to have written anything about his impressions, although other writers commissioned for such trips did produce glowing accounts of the remarkable phenomenon of Russian Jews working the land, or the resettlement of Jews in Birobidzhan and the Sovietization of the Tat (Mountain) Jewish farmers. ${ }^{12}$ On a tour of the Kiev region in fall 1935, Babel' admired the transformation of a wilderness into modern farmland with electricity. ${ }^{13}$

Later, he worked on the glossy propaganda magazine USSR in Construction, distributed around the world in several languages, and helped to produce an entire issue devoted to the sugar beet harvest in the Kiev region. ${ }^{14}$ Besides the special issue on Gor'ky, which he planned and edited, ${ }^{15}$ Babel' helped produce (according to Usher Spektor) an issue on industrialization in the Donbass in 1939, but is not mentioned in the credits, possibly because by then he was a "non-person". ${ }^{16}$ The associate editor of USSR in Construction was an old friend from Odessa, Evgeniia Khaiutina (who had married a White officer and lived in Berlin, and was now the wife of Ezhov, the secret police chief, who suspected Babel' of having an affair with her). USSR in Construction presented an idyllic picture to the West and helped prevent sympathizers and celebrities abroad guessing at the reality of forced collectivization and industrialization. 
De-kulakization of peasants in the Donetsk region, 1930s
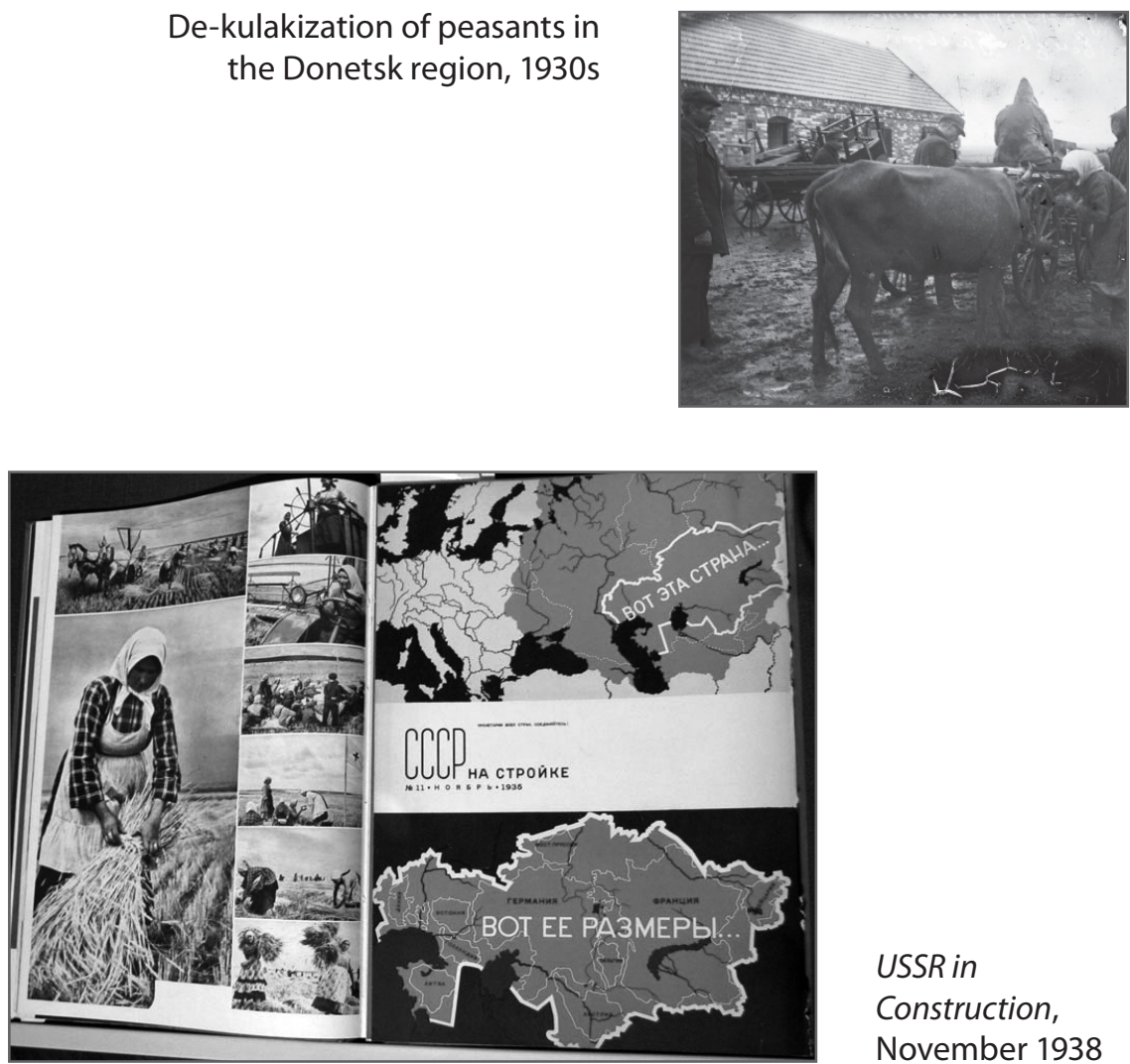

USSR in

Construction,

November 1938

Few foreigners ever got the chance to see the rotting corpses, the orphanages and penal colonies for children whose parents had been taken away, or the hard-labor convicts. When an important delegation visited, a Potemkin village was organized, the horror hidden away. ${ }^{17}$ We shall never know how uneasy Babel' was about collusion with the covering up of the harrowing truth.

The intense collectivization which began in 1929 came with the consolidation of Stalin's power, after the defeat of Trotsky on the left and the crushing of Bukharin and rightist opposition. Political pressure, administrative measures, and forced requisition of grain to meet shortfalls in production were effective in ensuring that peasants voted for collectivization of their villages. The targets for collectivization set by the Five Year Plan were grossly inflated and repeatedly increased, while, in the absence of a strong Party base 
locally, officials were sent to enforce production quotas accompanied by mobilized Party activists, who were not given adequate agricultural training and many of whom had little familiarity with peasant life. The activists were told they were being sent into the countryside for a month or two and they were not to be afraid of taking extreme measures in procuring grain:

\begin{abstract}
"You must assume your duties with a feeling of the strictest Party responsibility, without whimpering, without any rotten liberalism. Throw your bourgeois humanitarianism out of the window and act like Bolsheviks worthy of Comrade Stalin. Beat down the kulak agent wherever he raises his head. It's war-it's them or us! The last decayed remnant of capitalist farming must be wiped out at any cost!"18
\end{abstract}

The unrealistic targets of mass industrialization and collectivization were, moreover, based on political aims (many economists were forced to recant or lost their positions).

In the next stage of forced collectivization, announced by Stalin in November 1929, whole villages and districts were to be collectivized. It is not clear whether the Soviet leadership foresaw the disastrous results of the crippling of peasant leadership and the destruction of the most efficient elements of agriculture, but what Robert Conquest has termed the "terror-famine" was horribly effective in establishing total Party control over the country and also wiping out remaining Ukrainian aspirations for independence. ${ }^{19}$ Together with the elimination of the Ukrainian cultural and intellectual leadership, the forced collectivization of the Ukraine destroyed an entire way of life. Babel"s story "Gapa Guzhva" tells of how the village, whose real name Babel' prudently changed, celebrates for the last time its almost forgotten traditional lifestyle and rhythms. ${ }^{20}$ The story opens with the village whore, Gapa Guzhva, a kind of local Liubka the Cossack, gallivanting and carousing at the celebration of six weddings. But the gaiety and abandon vanish overnight with the coming of enforced collectivization. The church bells are taken down, the grain is requisitioned, and Rakhivna, a wandering seer, takes refuge at Gapa Guzhva's, warning her of the impending visit of priests from the free church in Antioch, who are coming to spread 
the news of the end of Soviet power and its punitive destruction. She is later arrested and presumably deported or executed. Rakhivna reports that the Voronkov judge collectivized his village overnight and put nine kulaks in the cooler, who were found hanged the next morning. When Gapa faces the Voronkov judge, who has come to impose deportations and confiscation in the name of the authorities, she goes to the village council and jokes about collective life requiring everyone to sleep under one blanket. She has, apparently, been persuaded to un-sign herself from the collective farm by the other villagers. Later, she asks Judge Osmolovsky whether there will be any place for whores in the new order.

- Житье будет блядям или нет?

- Будет, - сказал судья, - только другое, лучшее. (Собрание сочинений, III, 157)

"Won't the whores be allowed to earn their living?"

"They will," the judge said, "But in a different, better way." (Complete Works, 651)

She goes out, fingering her necklace, and the icy night throws itself down on her. The equivocal ending leaves a chilling sense of foreboding about the future, and it is not clear whether Gapa Guzhva's spirited defiance has been muted into resignation, or (as Carol Avins infers) accommodation. ${ }^{21}$ The deathly predatory silence that envelops the village does not leave room for a redemptive ending which would fit a Soviet clichéd makeover into the new life, or an Easter-time renewal of life.

The definition of "kulaks" as a class enemy could include wealthy peasants (even Communists who had prospered during the NEP years) and anyone resisting the requisition of property. Individual kulaks had been exiled from Ukrainian villages and Cossack settlements throughout 1929, but, in February 1930, a decree was issued ordering the elimination of the kulaks as a class. ${ }^{22}$ Although tax lists were cited, the kulaks were mostly impoverished and yet condemned as kulaks. Henceforth the class enemy was to be identified ideologically, not economically, and once designated as a kulak, the peasant's fate was sealed, often also that of his family. The first category of hard-core kulaks (including former White 
soldiers) was to be arrested and executed or imprisoned; the second group included the families of those executed or imprisoned who were to be deported to remote areas; the last group was to be evicted and conscripted to labor or settled elsewhere, but was liable to imprisonment on the slightest infraction or on suspicion of opposing collectivization. Despite the pretense of voluntary association, many peasants were banished for refusing to join the collective farm; after witnessing a brutal round-up of recalcitrant peasants, one Party activist realized that the violent extortion and coercion were being abetted by the regional Party committee: "So this was the liquidation of the 'kulaks as a class'! A lot of simple peasants being torn from their native soil, stripped of all their worldly goods, and shipped to some distant lumber camps or irrigation works." ${ }^{23}$ Party activists had to be mobilized to help the GPU with the mass arrests. Resistance was useless in the face of armed officials, but there were reports of peasants selling or destroying their cattle and property and running away, many fleeing to factories in the cities in the hope of earning a crust of bread and escaping detection. An estimated thirteen million were deported. ${ }^{24}$ This is Babel"s description in his story "Kolyvushka" of Kolyvushka after he has been informed he will be deported:

Кобыла подтащила к нему розвальни, высунула язык и сложила его трубочкой. Дошадь была жереба, живот ее оттягивался круто. Играя, она ухватила хозяина за ватное плечо и потрепала его. Иван смотред себе под ноги. Истоптанный снег рябил вокруг пня. Сутулясь, Кодывушка вытянул топор, подержал его в воздухе, на весу, и ударил лошадь по лбу. Одно ухо ее отскочило, другое прыгнуло и прижалось; кобыла застонала и понесла. Розвальни перевернулись, пшеница витыми полосами разостлалась по снегу. Лошадь прыгала передними ногами и запрокидывала морду. У сарая она запуталась в зубьях бороны. Из-под кровавой, льющейся завесы вышли ее глаза. Жалуясь, она запела. Жеребенок повернулся в ней, жила вспухла на ее брюхе.

- Помиримось, - протягивая ей руку, сказал Иван, помиримось, дочка... (Собрание сочинений, III, 160)

The mare came over to him dragging a sledge behind her. She hung out her tongue and then curled it up. She was with foal and her belly 
was heavily swollen. She playfully nudged and nuzzled her master's shoulder. Kolyvushka looked down at his feet. The trampled snow lay in ripples around the tree stump. Hunching over, Kolyvushka grabbed the axe, held it up high in the air for an instant and brought it down on the horse's forehead. One of her ears lunged back, the other fluttered and then slumped. She moaned and bolted to the side, the sledge toppling over and wheat flying in curved ribbons over the snow. She reared her forelegs into the air, tossing back her muzzle, and got caught in the spikes of a harrow by the shed. Her eyes peered out from under a streaming curtain of blood. She sang out in lament. The foal turned within her. A vein puffed up on her belly.

"Forgive me," Ivan said, stretching out his hand to her, "forgive me, my one and only." (Complete Works, 653-54)

This scene, which Avins likens to the almost religious frenzy with which the peasant Mikolka kills the mare in Crime and Punishment, ${ }^{25}$ expresses the utter despair that was released in the violence omitted from the official record of collectivization, as well as the powerlessness of subjugation and humiliation, and yet Babel"s precise observation nevertheless injects a human pain into the suffering of the animal: "She curled back her upper lip in despair" (Complete Works, 654; “Верхняя губа ее запрокинулась в отчаянии" [Собрание сочинений, III, 160]). As in the description of Afon'ka Bida's dying horse in Red Cavalry, cruelty is deflected into the response of a dumb animal. Observation is dispassionate, judgment is reserved. When Kolyvushka's relatives stop him smashing up the farm machinery, he puffs and pants as if he had been working hard. His hair has turned white. Kolyvushka is excluded from the meeting as a kulak and tries to rouse support from the rabble. Adrian Morinets, the village council committee member who accompanies the officials requisitioning Kolyvushka's home, voices his willingness to let him stay. Yet when the hunchback Zhitniak, the collective farm chairman, threatens to go and get Timish's gun and shoot him, Kolyvushka leaves the village, never to be seen again.

Those who "voluntarily" handed over their grain and joined the collective farm evidently "decided to face starvation at home rather than banishment to the unknown." ${ }^{26}$ The decisions were generally 
made by outsiders (regional Party officials, Komsomol members, soldiers, and workers) under directions from Moscow. In Mikhail Sholokhov's Virgin Soil Upturned (Поднятая целина, 1932), Semion Davidov, a Putilov metal worker mobilized to set up a collective farm on the Don, Gremiachii log, cites Stalin's speech in Pravda to refute the local village council chairman's Leninist position and, overcoming Nagulnov"s more strong-arm methods, uses his powers of persuasion to win over the middle and poor peasantry and liquidate the kulaks. Anti-Soviet intrigue simmers, but enemies are clearly identified and revolt quelled with cunning and skill. The pretentious and treacherous former White officers scheming to bring back the ancien régime, pale next to the hearty farm workers who, like the amiable ex-sailor Davidov, are excited at any prospect of manual labor, and relish bringing in rich harvests. Under the caring and thoughtful guidance of the representative of the regional Party committee, comrade Nesterenko, an old fighter ready to sacrifice himself for the cause, Davidov uses the authority of the Party to get the laborers to comply with his orders, under threat of being branded subversive counter-revolutionaries, and former friends and neighbors are treated as class enemies. He gets them to work on rest days and to desist from bringing a priest to pray for rain, he drags the women back from going to church, and takes care of hunger and want. Faced with the parched virgin earth, he never despairs or gives up. As a dedicated Communist and respected chairman of the collective farm, he knows he must extricate himself from the snares of Lushka, a wanton young woman in the village estranged from her husband, the communist nucleus secretary Nagulnov, and secretly in love with the banished kulak's son Timofei, who has returned from exile to wreak vengeance. Betrayal is everywhere.

There is little mistaking the jubilation in Sholokhov's novel with which the kulaks are evicted from their homesteads and every single piece of property requisitioned. There is no sympathy for the dispossessed families, and resistance serves to legitimize arrests and deportation. Not all Party activists could stomach unflinchingly the heart-wrenching scenes of families being thrown out of their homes and all their goods confiscated (sometimes even clothes they were 
wearing). At one point in Sholokhov's novel, Andrei Razmetnov refuses to turn out any more kulaks:

- Я не обучен! Я... Я... с детишками не обучен воевать!.. На фронте - другое дело! Там любому шашкой, чем хочешь... И катитесь вы под разъэтакую!.. Не пойду! ... У Гаева детей одиннадцать штук! Пришли мы - как они взъюжались, шапку схватывает! На мне ажник волос ворохнуяся! Зачади их из куреня выгонять... Ну, тут я глаза зажмурил, ухи заткнул и убег за баз! Бабы по-мертвому, водой отливали сноху... детей... Да ну вас в господа-бога!.. ${ }^{27}$

"I am not trained. I... I... I haven't been trained to fight children. It's a different matter on the front. You can cut down who you like there! You can all go to hell! But here-I'm not going on. ... Gayev has eleven children. When we came they all began to scream and shout in wild terror. My hair stood on end! We began to turn them out of the house, but then I had to shut my eyes and my ears, and run away. The women lying in a faint, pouring water over them... the children... you can all go to hell!" 28

He is silenced by Davidov's reminder that there was no pity for workers before the Bolshevik Revolution, when his mother had to sell her body to buy bread, and there can be no pity for class enemies now. But when women revolt and seize the grain, Davidov is beaten and the grain is only returned after the use of force.

Discipline was strict, and chairmen of village councils or officials who did not comply with de-kulakization quotas, or who helped the victims, were replaced (as is Ivashko, the regional Party committee representative, in Babel"s story "Kolyvushka"). Bukharin testified how much the collectivization campaign brutalized Party workers, inuring them to any humanity as they became efficient parts of the same killing machine that was to destroy so many lives in the Great Terror; those who participated "became professional bureaucrats for whom terror was henceforth a normal method of administration." ${ }^{29}$ Some, it is true, were stunned by the revelation that "excesses" were not local incidents but part of the system, yet were consoled by the overall achievements of modernization of agriculture and industry in the first Five Year Plan (no mean feat given Russia's backwardness). In any case, they had no way 
of communicating what they had seen in the village. ${ }^{30}$ Very often, insubordination or non-compliance would mean trouble for both themselves and those they were trying to help. Yet most of the Party activists obeyed orders unquestioningly, having been told that this was a war against a cunning enemy sabotaging collectivization and the necessary modernization of agriculture. Some were sincerely enthusiastic about doing their bit for the communist cause, as if it were the civil war again, and some were filled with hatred for the peasantry.

I became a member of the Party activist committee too. The activist committee included all kinds - those who believed the propaganda and who hated the parasites and were on the side of the poorest peasantry, and others who used the situation for their own advantage. But most of them were merely anxious to carry out orders from above. ... And the worst were not those who really believed the destruction of the kulaks would bring about a happy life. ... The most poisonous and vicious were those who managed to square their own accounts. They shouted about political awareness - and settled their grudges and stole. ${ }^{31}$

Those who followed their conscience and resigned from the Party were denounced in Pravda, and some were tried for sabotage. There was nevertheless some peasant opposition, occasionally violent, and sporadic revolts, which were ruthlessly repressed. ${ }^{32}$

In the face of resistance, Stalin called a tactical retreat in his article "Giddy from Success" in Pravda, 2 March 1930, in which he blamed local officials for excesses and distortions which threatened the loyalty of the peasants to the state. However, Stalin was not to be deterred from putting an end to the freedom of the peasantry, who began to regard themselves as Soviet serfs. As a concession, peasants were allowed a private allotment, but the option to leave the collective farm was restricted and unattractive. When peasants opting out of the collective farm demanded the return of livestock and equipment, they were offered an inferior exchange or were told they belonged to the fund of the collective farm. When, in Sholokhov's Virgin Soil Upturned, Naglunov, whose expulsion from the Party has been reduced to a reprimand for misdemeanors, argues they are better off without those who want to opt out, he is told his 
political growth is incomplete and he should not shoot his mouth off about the "excesses" and "deviations" of the regional committee. ${ }^{33}$ Tools and machinery were in the hands of the state, and the MTS tractor stations were poorly equipped, so that the high targets of grain procurement in 1932, enforced severely by draconian laws that included punishment by death for minor offences, caused real hardship and mass famine. ${ }^{34}$ Moreover, despite the propaganda line about the dire necessity for the transformation of Soviet agriculture, and for this new social revolution, there was no plan of how goals were to be achieved. Stores were neglected and provisions left rotting. Millions were starving to death or subsisting on nettles, rodents, and horse manure (there were also reports of cannibalism), while grain was being shipped out and milk turned into butter for export. After Stalin's jubilant declaration that collectivization had been completed in 1933, Party activists were once more mobilized to force the remaining peasants, many barely able to walk, to bring in the harvest, this time under the surveillance of the secret police, who hampered efforts to feed local peasants bringing in the harvest and threatened activists with expulsion from the Party or arrest if they did not obey orders. ${ }^{35}$ Some seven million are thought to have perished in the Ukrainian mass famine.

The starving people were left to themselves. The state has abandoned them. In the villages people went from house to house, begging from each other. ... And occasionally they were given a handful of bran or a couple of potatoes. But the Party members gave nothing. Not out of greed, nor because of viciousness. They were just very afraid. ${ }^{36}$

\section{The Disappearance of an Author}

Answering questions at a reading of his stories in September 1937, Babel' said that he was writing about the transformation of the village, about the people in the collectivization campaign, in which he had "more or less" participated in 1929-1930 (Собрание сочинений, III, 392). As Babel' acknowledged, this was an event of the greatest importance in Russia since the October Revolution, and 
he clearly wished to penetrate the meaning of the contradictions and conflicts behind what was happening. Both "Gapa Guzhva" and "Kolyvushka" deal directly with the victims of collectivization. The force of the description is bound up with a monumental restraint that allows no emotional involvement, no partisan faltering in the relentless detachment of vision. No blame is apportioned. There is no justification. The final confrontation between Ivan and the hunchback chairman of the new collective farm becomes something of a religious procession, a half-hearted and hopeless popular uprising that resembles the Brueghelesque scenes of the crowd descending on the monastery in "The End of St. Нypatius" ("Конец Св.Ипатия"), not in pilgrimage, but to reclaim the place for the textile workers. ${ }^{37}$ One recalls also the ragged old men besieging the cemetery gates in "The End of the Old Folk's Home" ("Конец богадельни"). However, even if some of the villagers are prepared to speak up for him, Ivan, whose hair has turned white overnight, is forced to flee alone and is never seen again. The enormous snowy plains wedged tight against the jeweled skies and the stars falling down the well of the night make for a desperate vision of desolation and finality. In "Kolyvushka," Babel' described the village council meeting where the chairman seeks to win over the peasants with the promising consequences for the economy of the fundamental transformation of village life (the new collective farm "Awakening" will engage in dairy farming and market gardening, taking advantage of the profitable proximity of Kiev), but the enormous human price is only too apparent.

This time there was no diary, and no intermediary peripatetic narrator who could mediate the moral shock of what was happening. Not only was the scale of the mass deportations and forced starvation nationwide, but all was orchestrated by the state, efficiently and under strict ideological control. There was no room here for ambiguity or irony. How was it to be conveyed without compromising the writer's integrity?

An earlier story, "The SS Cow-Wheat" ("Иван-да-Марья"), had been ambivalent about the men who were sent to the Volga on grain procurement expeditions, and the narrator remains a fairly neutral observer (though does not fail to note drunkenness and 
anti-Semitism). Those were the years of War Communism, when the peasantry openly opposed the Bolsheviks, and the struggle to feed starving Petrograd required heroic efforts. Now, there was no space for neutrality, there could be no deviance from the Party line (even if it changed course), and if the job could only be done through force, this was justified by an ideology that rejected humanitarian principles as weak-kneed whimpering. If the narrator of the Velikaia krinitsa stories was to be an outsider, he could not be a detached observer. And yet, if he was a Party activist, how could he evoke empathy with the victims of unprecedented horror? In contrast to the Red Cavalry and Childhood stories, Babel' seems to have eschewed an I-narrator, erasing any authorial position and robbing the reader of any moral guidance in facing the harsh facts of collectivization. The regional Party officials and activists are portrayed as only too human, not as callous monsters. Ivashko, whom the village has given a rough time, cannot risk showing any familiarity to Gapa or the other villagers.

Положив на стол руки, Ивашко сидел перед мятой, обкусанной грудой бумаг. Кожа его возле висков сморщилась, зрачки больной кошки висели в глазницах. Над ними торчали розовые голые дуги. (Собрание сочинений, III, 151)

He was sitting in front of a pile of crumbled, tattered papers, his hands resting on the table. The skin on either side of his forehead was wrinkled, and in his eyes hung the pupils of an ailing cat. Above them bulged the arches of his bare pink eye sockets. (Complete Works, 646)

The Voronkov judge, who replaces him, is a legend in his time, and has been nicknamed "216 per cent" for his rigor in obtaining grain requisitions. He is depicted as a weary older man, chewing bread and onions and poring late at night over a copy of Pravda, instructions from the regional committee, and the bulletins of the Ministry of Agriculture department in charge of collectivization (Собрание сочинений, III, 157; Complete Works, 650). He has taken off his spectacles and is partly covering his eyes with the palm of his hand. Judgment is left to the reader, while the setting (in contrast to the tranquil, luscious scenery of the steppe in Virgin Soil 
Upturned) brings home the unrelenting effects of a brutal reality. Kolyvushka's family flees without waiting for their deportation into the inhospitable, icy desert outside the village,

Ветер мял снизу и стонал в этой пустыне, рассыпая голубые валы. Жестяное небо стояло за ними. Алмазная сеть, блестя, оплетала небо. (Собрание сочинений, III, 162)

The wind spiraled in this desert, pummeling and moaning, scattering its blue waves behind which a mesh of diamonds wound sparkling. (Complete Works, 655)

After Kolyvushka bangs his keys down on the table at the village council meeting, from which he is excluded as a kulak, he storms out, leaving the committee members alarmed about his intentions:

Ночь была дилова, тяжела, как горный цветной камень. Жилы застывших ручьев пролегали в ней; звезда спустилась в колодцы черных облаков. (Собрание сочинений, III, 163-64)

The night was lilac and heavy, like a bright mountain crystal. Veins of frozen rivulets lay across it. A star sank into a well of black clouds. (Complete Works, 656)

The world of Velikaia Krinitsa is stark, merciless, and uncompromising. There is no positive socialist hero here like Sholokhov's Davidov, and no guiding ideology framing the narrative (though, when pressed to name influences and allegiances among contemporary Soviet writers, Babel' said he approved of the direction Sholokhov was taking in neo-Tolstoyan realism [Собрание сочинениน̆, III, 396-98]). In fact, information is sparse and must be gleaned from the few words of dialog. No room, however, is left for ambiguity.

"Gapa Guzhva" (dated Spring 1930) appeared in Novyi mir in 1931, but "Kolyvushka" seems to have been unpublishable and was first published abroad in 1963; it first appeared in the Soviet Union in a remote central Asian journal in 1967. Other parts of Velikaia Krinitsa were announced for publication in Novyi mir in 1931-1932, but never appeared: these were "Adrian Morinets" ("Адриан Моринец”), “Ноnеу” (“Мед”), and “Spring” (“Весна”). A story "Sulak" ("Сулак"), set in 1928, which had been announced in 1932 
and published in 1937 in a collectivization movement magazine, might relate to the Velikaia krinitsa sequence, or it may belong to a long-standing project about the capture of anti-Bolshevik partisans in the Ukraine; at one point, someone felt the story needed updating, and the archival manuscript is given the title "The Spy" ("Шпион"), more in keeping with the paranoiac mood of the times. We cannot know what harrowing accounts the lost or planned chapters may have contained. It is also difficult to imagine how Babel' maintained his optimistic hope for a socialist future after what he had personally seen in Ukrainian collective farms in the Kiev region at the height of the collectivization campaign in 1930. Since openly siding with deported kulaks would have been considered treacherous and outsiders would have been identified with the authorities, it is hard to imagine how Babel' could maintain the stance of an observer. This was surely more difficult than in the First Horse Army, where Babel' seems to have acted as translator at interrogations of prisoners and taken on other tasks beyond that of military correspondent. Certainly, writers were expected to participate in the brigades of Party activists and not accompany them as mere tourists. ${ }^{38}$ Did Babel' record the painful scenes and still side with the Party activists? Or perhaps he reacted like Lev Kopelev, an enthusiastic Party activist sent to the Ukraine in the final grain collection of 1933:

I heard the children ... choking, coughing with screams. And I saw the looks of the men: frightened, pleading, hateful, dully impassive, extinguished with despair or flaring up with half-made daring ferocity. ... It was excruciating to see and hear all this. And even worse to take part in it. No, it was worse to be present without taking part than when you tried to persuade someone, to explain something... And I persuaded myself, explained to myself, I mustn't give in to debilitating pity. We were realizing historical necessity. We were performing our revolutionary duty. We were obtaining grain for the socialist fatherland. For the five-year plan. ${ }^{39}$

We believed, despite what we ourselves had seen, learned, experienced..$^{40}$

Or did Babel' intend, as Platonov did in The Foundation Pit (Котлован, written 1929-1930, but published in Russia only in 
1987), to imbue the utopian vision of socialism with sadness and despair $?^{41}$ In Platonov's fantastic allegory, Nastia dies at the end, and the hope which the shock workers who were conscripted to the collective farms had invested in the USSR is laid to rest. The triumph of collectivization in bringing mechanization and a new life was celebrated in propaganda films like Alexander Dovzhenko's Earth (Земля, 1930), or Vladimir Kirshon's play Bread (Хлеб, 1930), both of which emphasized the threat from dispossessed kulaks. I have already noted the fate of Eisenstein's Bezhin Meadow, which was banned in March 1937 for deviating from the correct ideological treatment of collectivization, although it too shows the kulaks' vengeance; in this case a father murders the son who denounced him for planning to wreck the collective farm. ${ }^{42}$ Hand in hand with the purges, the collectivization and industrialization campaigns were ruthlessly implemented in the name of Soviet power. Their success and benefits were officially sanctioned myths, and the only criticism permitted was that from the mouth of Stalin. However, apart from Sholokhov's Virgin Soil Upturned, which was serialized in Novyi mir just a few months after "Gapa Guzhva" appeared in that journal and which marked the official parameters for depiction of collectivization, ${ }^{43}$ the subject was generally taboo in fiction until after Stalin's death. Later, after reading (in samizdat) Vasily Grossman's Forever Flowing (Все mечеm, 1970), or Solzhenitsyn's Gulag Archipelago (Apxunerar ГУЛАГ, 1958-68; published abroad 1973), diehard believers like Lev Kopelev wrote in their memoirs of their disillusion, wondering how they could have been part of all this.

Babel' did not succeed in publishing other collectivization stories and the book he had promised in his self-defense at the public hearing at FOSP in 1930 did not materialize. Two stories, "Sulak" and "Oil" seem on the surface to describe a triumphant Bolshevik position on wiping out the vestiges of Ukrainian nationalist resistance, on the one hand, and celebrating Soviet achievements in the oil industry, on the other. Yet in "Sulak" the narrator, who appears to be on the side of the Bolsheviks and speaks as part of a hit team hunting down the fugitive, does not actually take an ideological position, while in "Oil" the boisterous woman writing 
about her life manages (in the first, uncensored publication of the story) to report, alongside her unflagging zeal for her work in the oil refining industry, mass arrests of specialists and overinflated production targets. The seething bustle in Moscow of a socialist society under construction is nevertheless exciting:
вся разрыта, в окопах, завалена трубами, кирпичами, трамвайные линии перепутаны, ворочают хоботом привезенные из-за границы машины, трамбуют, грохочут, пахнет смолой, дым идет, как над пожарищем....(Собрание сочинений, III, 134)
[Moscow] is all dug up and full of trenches, pipes and bricks everywhere, a tangle of tram lines, machines imported from abroad are banging, tumbling rumbling, swinging their cranes, there's the stench of pitch, and there's smoke everywhere, like at a wildfire... (Complete Works, 692)

The conclusion seems to be that the ideal of the revolution remains untarnished and the battle for it continues. Yet it is still a tale of individuals, of Zinaida, a hysterical woman in the office who gets pregnant by Max Solomonovich, a Jew who is only interested in her because she is a shiksa with Russian aristocratic origins, and of Claudia herself, who persuades her to have the baby and who speaks out fearlessly at a meeting to defend a colleague daring to protest the impossible demands of Party officials. Claudia is the principled idealist who refuses to have anything to do with Shabsovich when he is promoted and has access to privileges. It is a tale of dedication to an ideal and to hard work.

Babel', we know, was attracted to the Chekists, and the ending of "The Journey" (as I have suggested) could be read as a wishfulfillment of empowerment by the Jewish intellectual who had been liberated from Tsarist oppression. In "Froim Grach," the old gangster is killed in cold blood, and the agent sent down from Moscow understands nothing of old Odessa, which has been brought to an end. There is a voyeuristic fascination with what makes these men tick in Babel's interest as a writer in those who wielded the power of death. Babel' may in fact have been a habitual voyeur, if we are to judge by an early story later entitled "Through the Fanlight" (1915), the abortion scene in "Mama, Rimma, and Alla" 
(1916), and a draft of a Red Cavalry story describing a Red Army man having intercourse wth a woman dressed in a man's uniform in a hotel room, which Babel' thought would provide material for a social analysis of Russian sex (Собрание сочинений, II, 361). The editor of Novyi mir, V. P. Polonsky, who published the collectivization story "Gapa Guzhva" in 1931, recorded his impression from Babel"s reading of the story that he had described a village, as in Red Cavalry, full of "blood, tears, sperm" (“кровь, слезы, сперма"). ${ }^{44}$ Polonsky found he had to deal with a painstaking craftsman and a fellow traveler anxious about his reputation, who would not be persuaded to hand over manuscripts until he was satisfied with them. All this was explained, Polonsky noted in his diary, by Babel"s tendency to become fixated with the extreme, with the extraordinary and grotesque side of human nature:

Бабель работал не только в Конной, он работал в Чека. Его жадность к крови, к смерти, к убийствам, ко всему страшному, его почти садическая страсть к страданиям ограничида его материал. Он присутствовал при смертных казнях, он наблюдал расстрелы, он собрал огромный материал о жестокости революции. Слезы и кровь - вот его материал. Он не может работать на обычном материале, ему нужен особенный, острый, пряный, смертельный. Ведь вся Конармия такова. А все, что у него есть теперь, - это, вероятно, про Чека. Он и в Конармию пошел, чтобы собрать этот материал. А публиковать сейчас боится. ${ }^{45}$

Babel' worked not only in the First Horse Army, he worked in the Cheka. His thirst for blood, for death, for killings, for all that was terrifying, his almost sadistic passion for suffering limited his material. He was present at executions, he observed shootings, he collected an enormous amount of material on the cruelty of the revolution. Tears and blood, this is his material. He cannot work on ordinary material, he needs the peculiar, the sharp, the pungent, the deathly. But then all of Red Cavalry is like that. And everything that he has now is, no doubt, about the Cheka. He went into the First Horse Army, too, to collect this material. But he is afraid to publish it.

The voyeuristic interest in rape in "At Bat'ko Makhno's" (discussed in the previous chapter), prostitution ("Through the Fanlight"; 
"The Chinaman"; “Tale of a Hardworking Woman"), and murder ("Beresteczko"; "The Journey") betrays no subject position, and yet a humanizing vantage point is introduced into the everyday banality of life, exposing what is both grotesque and extraordinary in the human condition.

The play on historical and religious myth was to become muted in Babel's prose of the late twenties and thirties, when Babel' drew on his colorful metaphors and sensuous imagery more sparsely and thus more devastatingly in his search for a new style and form. He nevertheless remained aware of the effect of the detached view of individual fates in an overbearing historical reality, as we see in the fragment that has survived of the novella The Jewess, which draws a poignant picture of the final demise of the Jewish shtetl and the move of a Jewish Red Army officer's family to Moscow. Boris Ehrlich has none of the complexes of Liutov, and his self-assured integration into the Soviet military elite contrasts with the shoddy, broken lives of his relatives, former Jewish traders ruined by the Bolshevik Revolution. Nor does his confidence in the future dispel his widowed mother's anxieties - traveling in the comfortable modern railway carriage, she cannot help worrying that someone will have to pay for this luxury. And while she assumes her maternal position by the samovar when Boris's comrades-in-arms come to visit, the smell of Jewish cooking in their new communal apartment in Moscow is not well-received.

Babel', who knew the truth about Stalinism, confided in very few friends (among them Ehrenburg and Boris Suvarin in Paris). ${ }^{46}$ Possibly, we will never know how much of that truth he managed to tell in the stories that have been lost to us. What is clear is that the collectivization book was conceived of as a multi-voiced tale that would give the viewpoint of both activists and dispossessed, without giving away an authorial position. Such a book could not be published in Stalin's Russia. 